\title{
Design of China's High-level Commercial Residential Product Integrating British Style
}

\author{
JU Rui Xin ${ }^{1, a^{*}}$ and ZHANG Zi Cheng ${ }^{2, b}$ \\ ${ }^{1}$ Shenyang New World Architecture Design Co., Ltd, No. 2-101, Xinlong St., Dongling District, \\ Shenyang 110179, Liaoning Provence, P.R. China \\ ${ }^{2}$ Northeastern University, No. 11 Lane 3, Wenhua Rd, Heping District, Shenyang 110819, Liaoning \\ Province, PR China \\ ajuruixinhagongda@163.com, b zhangzicheng2004@126.com \\ ${ }^{*}$ Corresponding author
}

\begin{abstract}
Keywords: British Style, Commercial Housing, Architectural Design, Programming Design, Construction practice.

Abstract. The residence community gradually becomes the main living space of China's large and medium-sized city residents with the development of the internationalization of urban living environment and internationalization process of urbanization. The more international, livable and convince residence community has become the main type of Chinese traditional residence in the modern international metropolis residential community. It is also the developing trend of residential style. The residence community Lvsha Jazzi Mood is one of the boutique commercial housing projects developed by Shenyang New World Architecture Design Co., Ltd., which has been received the favorable comments because of the planning and architectural design from the property developers. The "Nature and Human" design theme of British style was utilized through all the processes of scheme design, construction drawing and construction of the whole park. To give a better use of the British style in the planning and architectural design of this project, the research of the existing British style commercial housing and the analyzation of the works of classical architecture in various periods of the United Kingdom were executed. The successfully using of the design idea for the British style in commercial housing for Chinese traditional residence is benefit to the internationalization of the commercial residential building design market of China. In addition, it can provide references for the same type city in the development of commercial residential park construction program.
\end{abstract}

\section{British Classical Architectural Works in Different Periods}

In Britain, beside the beautiful natural rural scenery there are a wide variety of fascinating buildings. In different ages the architectural styles are different in the cities of different regions. The traditional classic architectural works such as Gothic architecture (A.D. 1200-1500), Tudor architecture (A.D. 1485-1603), Victorian architecture (A.D. 1840-1900) were still preserved in Britain under the impact of war and modern civilization.

Gothic architecture is a kind of original style of European architecture arts between the 12th and 15th centuries[1]. In Britain, many churches are Gothic architecture. Therefore, the architectural style of the most churches are the symbols of many Christian Philosophy. The characteristics of the Gothic architecture structure are as follows: 1) The ribbed vault is adopted. 2) Most of them are facing to the west and cross-shaped in plane. The cross is on behalf of the body of Christ. The wings of the temple are the straightened arms and the hemicycle temple located in the east are the head of Christ, respectively. 3) The main entrance located in the west. 4) Generally there will be a pair of tall symmetrical towers located in the both sides of the west main entrance. The circle rose windows can be found above the main doors. 5) The vertical line decoration is used in the outside of the wall and buttress. 6) Christian stories were carved in archdoors of the west front and north and south wing temples.

Tudor architecture were prevalent between the years of 1890 and 1940 in Britain [2]. The architecture design with the Tudor architecture style became the models after the buildings with the 
appearance of the construction of the Renaissance. The characteristics of the Tudor architecture can be briefly summarized as 1) The semi dry wood decoration was adopted; 2) Large sloping roof; 3) Staggered protrusion gable; 4) High and narrow doors and windows; 5) Small glass windows; 6) Tall chimney; 7) Plastering wattled wall.

Victorian architecture style appeared during the period of Queen Victoria in Britain from the year of 1837 to 1901 [3]. During this period the economics of Britain improved significantly because of the industrial revolution. The people in Britain pursuit fine housing. The new kind of architecture style appeared under the pushing of the human and the rich resources. The Victorian architecture has the following characteristics: 1) The sharp roof; 2) The window stretched out the wall of the house; 3 ) The corridors and balconies with roof around by railings outside of the house; 4) The outside of the wall coved with the wood like fish scale; 5) Having a steeple; 6) There is a window in the roof; 7) Round or square column; 8) Finely carved buildings.

\section{Introduction of the Project}

The project of residence community Shenyang Lvsha Jazzi Mood located in the Tiexi district, Shenyang city, Liaoning Province, China. Fig. 1 shows the location of this project. The total plot area is about 39826 square meters. The total gross floor area is 95170 square meters. This project is composed of multi-storey residence dwelling, high-rise residence and commercial buildings along the street. The residential park was consisted of the main building group with British style. It is rich in modern British cultural consciousness, commercial element and regional characteristics. The residential park has become the humane and commercial landscape and city residential representative building in the area.

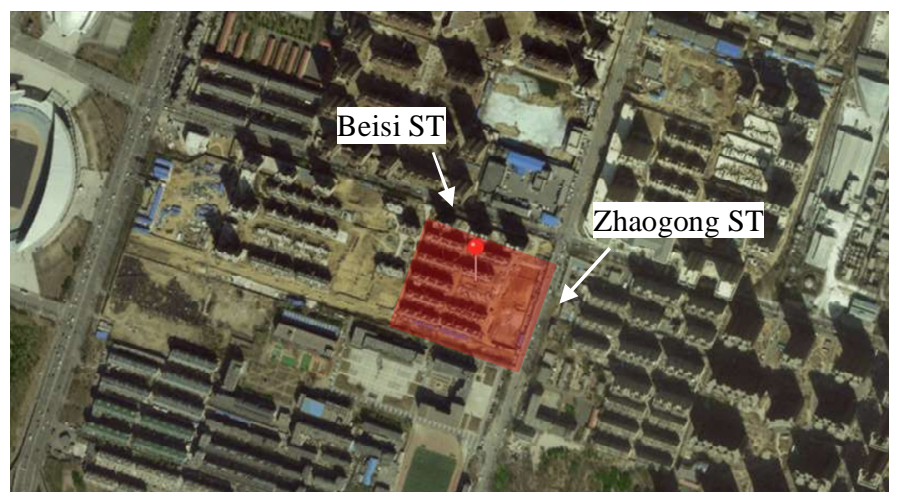

Fig. 1 Location of the Shenyang Lvsha Jazzi Mood park

\section{Design of the Planning Scheme}

Planning Subject. The scheme design was executed through the investigation of British architecture. The British design theme of "Human and Nature" for the residence community of Shenyang Lvsha Jazzi Mood park was successfully proposed base on the considering the geographical position characteristic, the shape of the ground and the original British architectures. In addition, the living habits of Chinese people was also given the significant attention and considerations. The general layout of the residence community is given in Fig. 2(a). The aerial view of the residence community is shown in Fig. 2(b). The residential district green rate is $30 \%$. There is a small stream running though. The trees and grass with long growth period are planted. The garden followers are also used to decorate the residence community. The people can feel like melting into the nature when she is working along the winding path. The harmony and interaction between human and nature was successfully constituted.

Landscape Planning System. Borrowing the characteristics of symmetry with the central axis of British style, the main axis of landscape was designed in the main entrance of the residence community. The main visual axis of landscape green space, the traffic landscape planning route and landscape green 
space between buildings are designed based on the main axis. The building groups of the residence community are symmetrically located along the main axis and organically link with the main axis. The different elements such as landscape along the road, private garden, air garden etc. permeate to each other. The environmental characteristics of multi - level three-dimensional was formed. The trails in front of independent buildings are designed as cul-de-sac. The English-style landscape sketch, green trees, events plaza with the English-style landscape sketches are set up along the both sides of the trails. The landscape along the road and the partially open plaza effect can be enhanced. The landscape nodes analysis chart is given in Fig. 3(a).

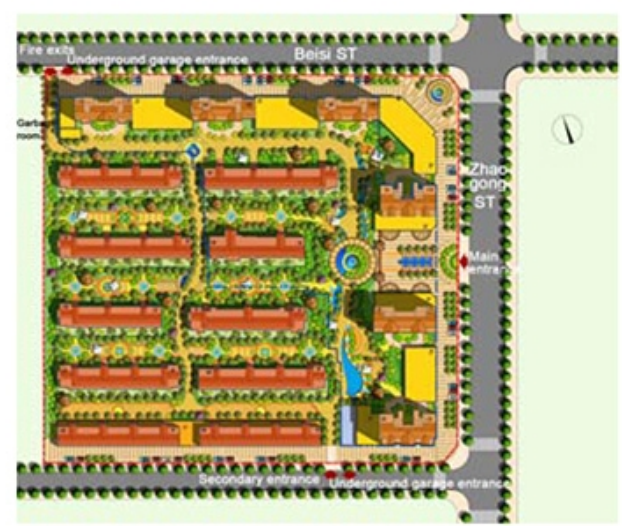

(a)

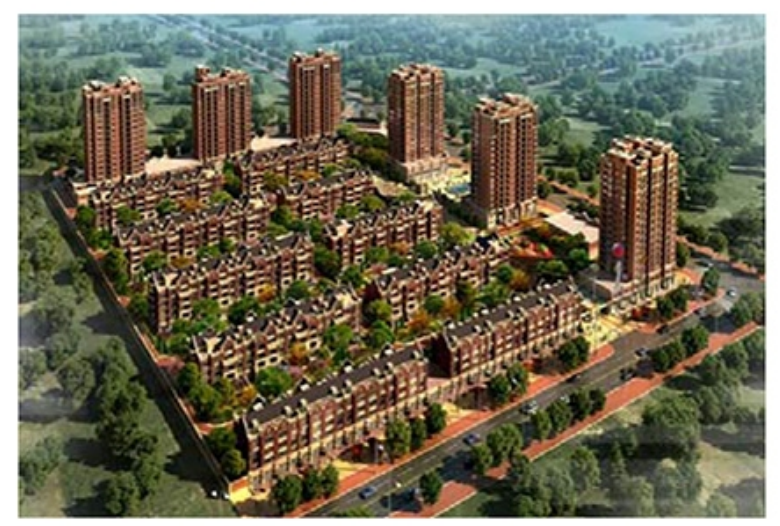

(b)

Fig. 2 The general layout and aerial view of the residence community ((a) general layout, (b) aerial view)

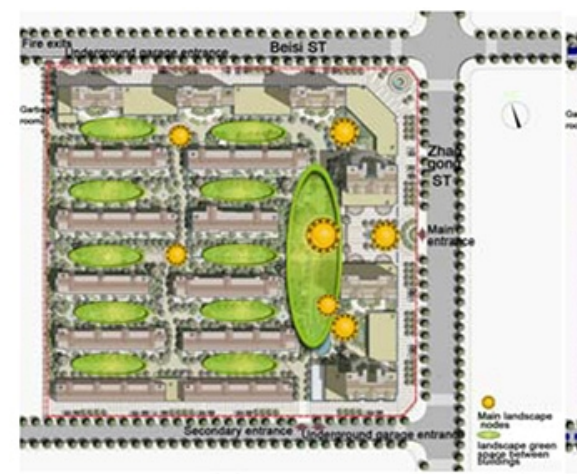

(a)

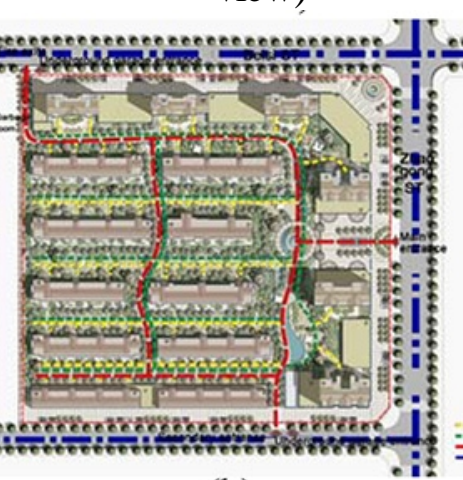

(b)

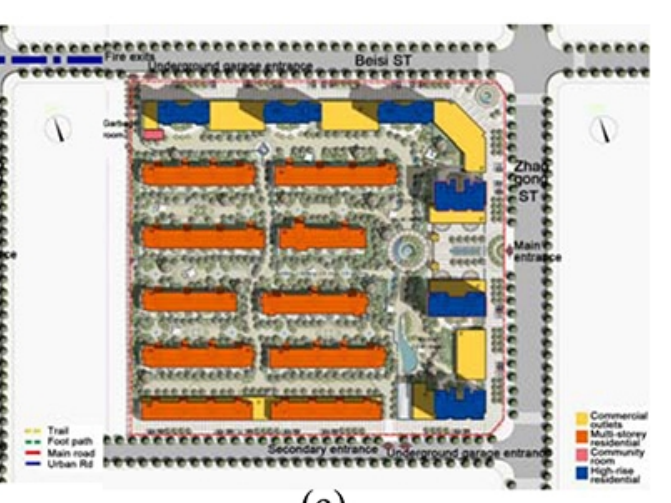

(c)

Fig. 3 The charts for landscape nodes, traffic planning and design and distribution of the buildings of the residence community ((a)Landscape nodes analysis chart, (b)Traffic planning and design chart (c)The distribution of the buildings in the park)

Traffic Planning System. The concept of coexistence of people and vehicle was used in the designing of the traffic planning system. Fig. 3(b) shows the traffic planning and design chart of the residence community. The main entrance located in the east side of the residence community which approaches to the Zhaogong ST, one main busy street in Shenyang. The secondary entrance is in the south of the residence community. The entrance of the underground garage is in the north and the secondary entrance. The circle driveway sited inside the park is the main artery of the residence community. The footpaths distribute in the landscape system.

\section{Architecture Design Scheme}

Functions of the Park. The park can be divided into three main parts: multi-storey residential district, high-rise residential district and street commercial district. The multi-storey residential district located in the center of the park and is mainly composed of the four or five storey buildings. In the west of the park two high-rise buildings with 17 storey buildings and one high-rise buildings with 16 storey building can be found. There are three 17 storey buildings in the east part of the park along the street. 
The distribution of the buildings in the park is given in Fig. 3(c). The residential mainly towards to the south. The public facilities such as commercial outlets, garbage room, property room and club house are also included in the residence community.

Architectural Style Characteristics. The design of facade of the buildings learned from the Britain style architecture. Fig. 4 shows the photos of the buildings in the residence community. The sharp triangle structure which is popular in the Britain style architecture were adopted in top of the buildings. The pilaster structure and style of Britain architecture is also used in the design of the buildings. The characteristics such as the small windows style, the stone in the pilaster, the red brick, the window stretched out the wall of the buildings, English style landscape sketch, arched door, foyer with the pilasters in red and white color, parapet with small pilasters, the terrace with wipe angle and etc. are designed similar to the ones in the Britain style architecture.

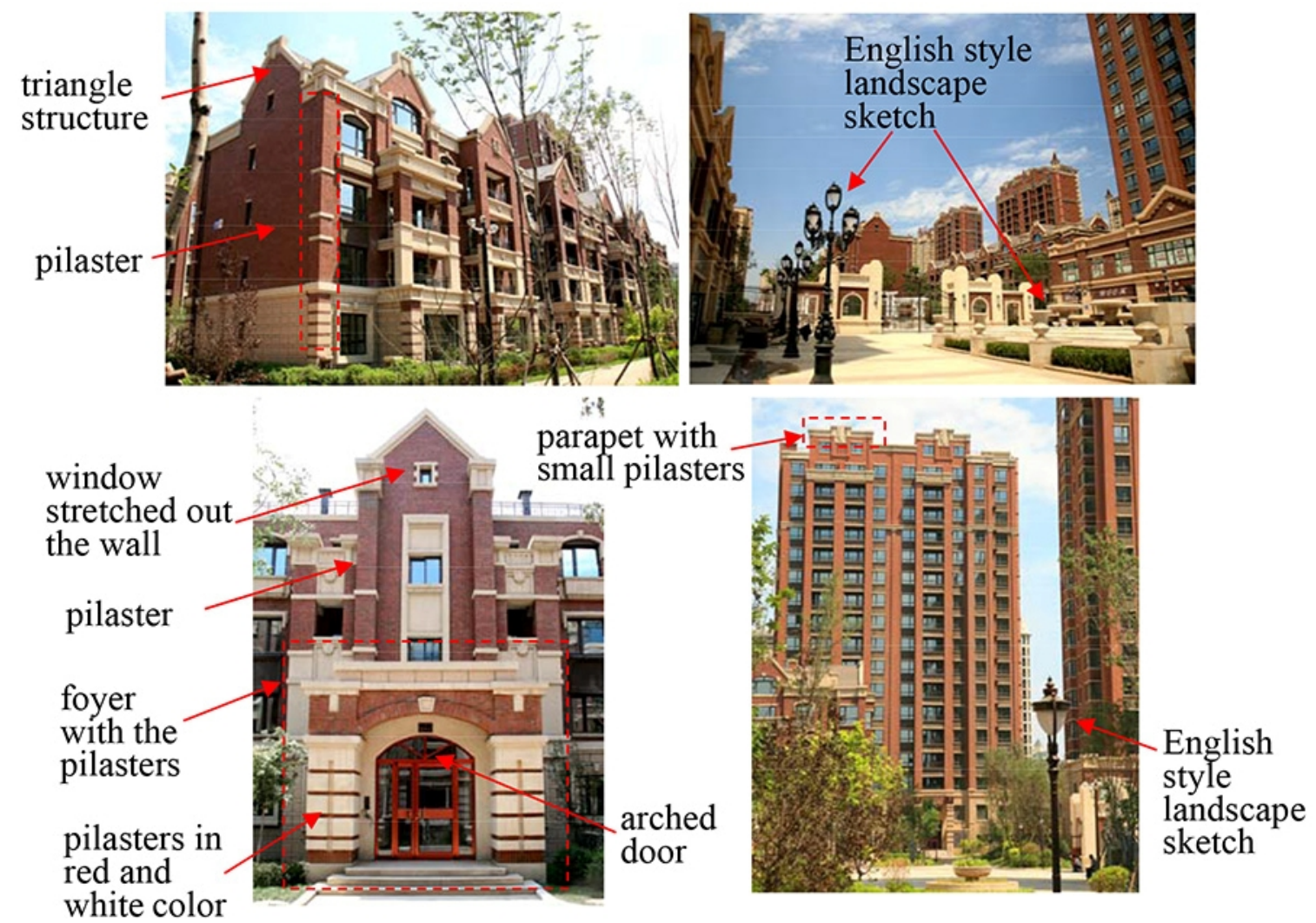

Fig. 4 The photos of the real buildings in the residence community.

\section{Summary}

Based on the analyzing the characteristics of British classical architectural works in different periods and considering the living habits of Chinese people as well as the actual geographical features, a modern residence community was designed. From the photos of the real buildings it can be concluded that the newly designed residence community successfully fused the elements of the Britain style architecture. The residence community embodied the characteristics of human and nature harmonious, strong British style and internationalization.

\section{References}

[1] Paris A. S., An Architectural History, Yale University Press, State of Connecticut, US, 1996.

[2] https://en.wikipedia.org/wiki/Tudor_architecture.

[3] https://en.wikipedia.org/wiki/Victorian_architecture. 